\title{
Contenciosos Brasileiros na Organização Mundial do Comércio (OMC): Pauta Comercial, Política e Institulições*
}

Daniel Arbix**

\section{Introdução}

$(2$ fortalecimento da economia e do comércio exterior brasileiros nos últimos anos insere-se em um quadro de estabilidade normativa e internacional marcado pelo enrijecimento jurídico do sistema multilateral do comércio. As regras da Organização Mundial do Comércio (OMC), progressivamente mais globais, alcançaram mais transparência no que diz respeito ao comércio de bens e serviços, a barreiras comerciais tarifárias e não tarifárias e a medidas de defesa comercial, além de regulamentarem uma série de outros tópicos da

* Artigo recebido em fevereiro e aprovado para publicação em abril de 2008.

** Mestrando em Direito Internacional pela Universidade de São Paulo (USP) e assessor da Secretaria de Assuntos Legislativos do Ministério da Justiça. E-mail: d.arbix@uol.com.br.

CONTEXTO INTERNACIONALRio de Janeiro, vol. 30, nㅡ 3, setembro/dezembro 2008, p. 655-699. 


\section{Daniel Arbix}

agenda doméstica de seus membros, como subsídios e direitos de propriedade intelectual.

Como agente comercial pujante, o Brasil tem sido ator de peso nas negociações do sistema multilateral do comércio. Simultaneamente, tem se valido das normas da OMC para contestar políticas e medidas de outros membros da OMC. A escalada desses "confrontos", que possuem sensibilidade política variável, pode tensionar entendimentos diplomáticos e implicar o recurso à adjudicação de conflitos. O Órgão de Solução de Controvérsias (OSC) da OMC, nesse sentido, cumpre papel decisivo ao privilegiar a resolução negociada das disputas e, ao mesmo tempo, permitir o recurso a sanções críveis, a mecanismos de compensação e à adoção quase automática de suas decisões pela OMC.

As divergências comerciais insolúveis por meio de negociação entre os países envolvidos e que ultrapassem o âmbito da integração econômica regional - âmbito este muitas vezes dotado de sistemas próprios de solução de controvérsias - atingem seu ponto focal no OSC. O recurso do Brasil a tal mecanismo, portanto, é escolha relevante da política de comércio exterior, tanto pelo resultado dos contenciosos quanto pela percepção internacional sobre seu desenrolar.

Procura-se, no presente artigo, entender os processos de decisão que conformam essa escolha específica da política externa brasileira. Almeja-se vislumbrar explicações, para as demandas propostas pelo país ao OSC, atentas às composições políticas e aos múltiplos interesses que perpassam agentes e órgãos públicos. Procura-se trabalhar a hipótese de que o condicionamento dessa escolha não está fortemente vinculado ao desenho institucional das políticas de comércio exterior - isto é, não se encontra concentrado na Câmara de Comércio Exterior (Camex). Para isso, parte-se do instrumental analítico da foreign policy analysis (FPA; em português, análise de política externa) com ênfase nos processos decisórios. Segundo 


\section{Contenciosos Brasileiros na Organização \\ Mundial do Comércio (OMC)...}

Hudson e Vore (1995, p. 210): “A abordagem dos processos decisórios pela FPA rompe com a visão monolítica dos Estados-nação como atores unitários". 1

O texto organizar-se-á do seguinte modo: após uma breve recomposição do quadro constitucional do qual fluem as decisões sobre contenciosos comerciais internacionais, serão explicitados a evolução e o funcionamento das instituições responsáveis pela política de comércio exterior, analisados a partir das mudanças decorrentes dos processos de liberalização comercial e de redemocratização do país. Em seguida, serão contextualizadas as demandas propostas pelo Brasil ao OSC e confrontadas com as expectativas resultantes do esquema institucional que as deveria conformar. $\mathrm{O}$ artigo finaliza com uma reapreciação, à luz dos problemas institucionais identificados, da performance brasileira nos contenciosos internacionais da OMC.

\section{Política de Comércio Brasileira - Estrutura, Instituições e Policy}

Ao contrário dos muitos temas instáveis na ordem constitucional, sujeitos a modificações constantes e ao engessamento de políticas públicas, apenas as diretrizes amplas para a política externa foram cristalizadas na Constituição de 1988. Os objetivos e balizas presentes, em especial em seu artigo $4^{-}$, pertencem à dimensão da normatividade constitucional - definindo Estado e Nação e traçando os parâmetros gerais do jogo político (COUTO; ARANTES, 2006). As previsões constitucionais sobre política externa não condicionam substancialmente as decisões concretas de governo (policy).

No que diz respeito à alocação de competências, o primado do Poder Executivo nas decisões "internacionais" salta aos olhos. ${ }^{2}$ Cabem-lhe a alteração unilateral de tarifas e a negociação e assinatura de acordos comerciais, ainda que seja necessária a ratificação do Legislativo 
(JALES, 2007, p. 40). Como o Legislativo exerce controle somente $a$ posteriori, a implementação da política externa ocorre, em regra, por meio de atos infralegais também do Executivo, relegando a segundo plano a consulta ao Congresso e suas possibilidades de atuação (LIMA; SANTOS, 2001, p. 141-142). ${ }^{3}$

As políticas de comércio exterior seguem esse funcionamento institucional. Outras medidas, por exemplo, de apoio a exportações, são em parte dependentes do aval legislativo, uma vez que traduzidas em um leque de possíveis medidas de financiamento, crédito e seguros, medidas cambiais e medidas tributárias. Mesmo nesse tocante, porém, as prerrogativas do Executivo sobressaem-se: o Ministério da Fazenda detém poder fiscalizador e de controle sobre o comércio exterior, ${ }^{4}$ e as linhas de crédito e seguros para o comércio internacional são moldadas ou estimuladas pelos órgãos de supervisão do sistema financeiro nacional, pelos bancos públicos e por agências de fomento, todos vinculados ao Executivo. ${ }^{5} \mathrm{O}$ legislador médio não tem incentivos para se ocupar da política de comércio exterior, que combina complexidade e distância dos temas eleitoralmente centrais.

A competição política referente às escolhas do comércio exterior tem, portanto, nas instâncias decisórias do Executivo, suas arenas relevantes. Em grande medida, a atuação de conjuntura independe do aval do Congresso ou da sociedade civil organizada, "desde que as decisões do governo não contrariem a normatividade constitucional, respeitando os limiares e os limites estipulados" (COUTO; ARANTES, 2006, p. 49). A policy comercial forma-se, assim, no seio do Executivo. ${ }^{6}$

A ausência de participação efetiva do Congresso, segundo alguns autores, caracteriza situação de plena "abdicação de autoridade" (LIMA; SANTOS, 2001, p. 131). ${ }^{7}$ Com a decisão concentrada no Executivo, é natural que o aparato burocrático domine a formulação 


\section{Contenciosos Brasileiros na Organização}

Mundial do Comércio (OMC)...

da política externa e, por consequiência, que uma série de medidas seja gestada com transparência reduzida. ${ }^{8}$ A atmosfera política resultante seria marcada por decisões instáveis, pressões burocráticas, tendência ao favorecimento de grupos específicos - sem controle ou monitoramento incisivo de outros órgãos governamentais e da sociedade civil (LIMA; SANTOS, 2001, p. 132).

Esse descolamento do Legislativo com relação à política de comércio exterior é visível nas negociações comerciais, mesmo que se presuma que o Executivo é capaz de antecipar as preferências do Congresso e que as incertezas eleitorais podem arrefecer movimentos pró-liberalização comercial (MILNER; ROSENDORFF, 1997). Em planos decisórios distantes das negociações internacionais com importância comercial até mesmo mais acentuada, não há sequer a necessidade de ratificação dos atos do Executivo. $O$ controle sobre as barganhas domésticas e internacionais passa a depender, portanto, de transparência institucional e de mecanismos de participação da sociedade civil.

Componentes da política de comércio exterior, as decisões sobre contenciosos comerciais obedecem a dispositivos constitucionais extremamente vagos, como a preferência pela solução pacífica dos conflitos. ${ }^{9}$ Normas programáticas referentes à inserção brasileira no sistema multilateral do comércio não regulamentam as escolhas de demandas, que se forjam em jogo político com múltiplos condicionantes internos e externos. Os internos são relativos, principalmente, a recursos humanos, materiais e de coordenação escassos (ARBIX, 2007). Os externos correspondem tanto à possibilidade estimada de vitória quanto à antecipação dos efeitos que a instauração do contencioso pode ter para as relações bilaterais do país, para os agentes econômicos diretamente envolvidos com a questão suscitada e para o plano multilateral (JACKSON, 2004). 


\section{A Abertura Econômica e as Novas Configurações Institucionais}

No final dos anos 1980, os instrumentos de incentivos, de crédito e de gestão da política de comércio exterior brasileira sofreram alterações drásticas. Remodelado pelas necessidades do regime democrático, o Estado brasileiro precisou reagir a tensões econômicas estruturais com severos constrangimentos fiscais e de investimentos. A crise macroeconômica foi respondida com iniciativas de liberalização comercial, contrapostas à política então predominante de substituição de importações. Tais esforços foram acompanhados do desmonte das instituições responsáveis pelas políticas industrial e comercial, que focalizavam na época setores econômicos determinados (VEIGA; IGLESIAS, 2002, p. 56).

A ordem constitucional democrática erigiu-se em paralelo às evoluções da Rodada Uruguai, que desembocaram na criação da Organização Mundial do Comércio, em substituição ao regime do General Agreement on Tariffs and Trade (GATT; em português, Acordo Geral sobre Tarifas e Comércio). ${ }^{10}$ No entanto, se a institucionalização da liberalização comercial no plano externo foi acentuada, as políticas de estabilização dos anos 1990 resultaram em indicadores macroeconômicos frágeis que, principalmente pela apreciação cambial, permitiam exportações tímidas (MILNER; KUBOTA, 2005).

A extinção, em 1990, da Carteira de Comércio Exterior do Banco do Brasil (Cacex), órgão centralizador de instrumentos e normas relacionadas à promoção comercial, representou o nadir da atuação estatal recente de apoio às exportações e de estímulo relevante ao comércio exterior. A interação entre agentes públicos e empresariais desgastou-se, e o modelo centralizado da Cacex não foi adequadamente substituído, o que acarretou uma desfuncionalidade das políticas de comércio exterior (VEIGA; IGLESIAS, 2002, p. 56-59). 


\section{Contenciosos Brasileiros na Organização Mundial do Comércio (OMC)...}

Ao longo dos anos 1990, a crise econômica foi sendo gradativamente minorada. O ajuste macroeconômico dos governos FHC e Lula consolidou metas de inflação e regime de livre flutuação das taxas de câmbio desde 1999, superávit estrutural da conta comercial desde 2001 e níveis crescentes de superávit primário. Cenários interno e externo positivos, com a atração de volumosos fluxos financeiros, fortaleceram a economia brasileira. Simultaneamente, acirraram-se nos mercados-destino das exportações brasileiras medidas de defesa comercial e questionamentos sobre o respeito do país às normas da OMC. Acesso a mercados e promoção das exportações, incluindo financiamento, administração de incentivos fiscais e interlocução com o setor privado, tornaram-se candentes. Um novo desenho institucional para a política de comércio exterior fez-se necessário. ${ }^{11}$

As instituições voltadas ao comércio exterior foram revistas em 1995. A Camex foi então estruturada com a responsabilidade de coordenar as ações públicas em comércio exterior, incluindo uma extensa gama de temas e graus de atuação. Criada como órgão consultivo do Conselho de Governo, ${ }^{12}$ a Camex era presidida pelo ministro-chefe da Casa Civil e encarregada da articulação interministerial e dos contatos com os setores produtivos.

No entanto, em 1998 a Camex foi deslocada da Casa Civil para o Ministério do Desenvolvimento, Indústria e Comércio, o que gerou "uma ambigüidade institucional nítida" (VEIGA; IGLESIAS, 2002, p. 61), na medida em que deveria executar funções de coordenação ministerial, mas sua Secretaria Executiva era comandada por um Ministério específico. Buscou-se, em fevereiro de $2001,{ }^{13}$ remediar essa fragilidade institucional, com a reorganização das funções e publicação das decisões tomadas na Camex. Em outubro do mesmo ano, nova alteração obrigou que o órgão fosse consultado "sobre as matérias relevantes relacionadas ao comércio exterior, ainda que consistam em atos de outros órgãos federais". ${ }^{14}$ 
No campo da promoção às exportações, o Departamento de Promoção Comercial do Ministério das Relações Exteriores (MRE), desde 1997, trabalha em conjunto com a Agência de Promoção de Exportações e Investimentos (Apex). As relações entre a Apex, o MRE e o Ministério do Desenvolvimento, Indústria e Comércio Exterior (MDIC), em princípio mediadas pela Camex, geram relações próximas com agentes privados, no que diz respeito tanto a eventos de promoção comercial quanto a esforços por abertura de mercados. ${ }^{15}$

Pesquisa conduzida em 2001 (SOUZA, 2001) sugeriu o reconhecimento da Camex como centro decisório para a definição da política comercial e de promoção de exportações. Na época, era saliente a coordenação das atividades da Camex com o MRE e os Ministérios da Fazenda e da Agricultura, ainda que atritos fossem visíveis. Embora modificações tenham reforçado as competências da Camex, a inexistência de prerrogativas bem definidas dificulta a imposição das deliberações do órgão, tanto em matérias relacionadas à promoção das exportações quanto em negociações internacionais e outros temas de alta complexidade, decorrentes de fortes condicionantes externos, ${ }^{16}$ como a seleção de litígios internacionais.

\subsection{A Camex: desafios e limites}

Órgão coordenador da formulação da política brasileira de comércio exterior, a Camex é hoje formalmente responsável pela "adoção, implementação e a coordenação de políticas e atividades relativas ao comércio exterior de bens e serviços, incluindo o turismo." ${ }^{\prime 17}$ De seu Conselho de Ministros, instância interministerial de cunho acentuadamente político, participam os ministros-chefe da Casa Civil; do MRE; da Fazenda; da Agricultura, Pecuária e Abastecimento; do Planejamento, Orçamento e Gestão; do Desenvolvimento Agrário; e do MDIC, que a preside. ${ }^{18}$ A Camex possui ainda uma Secretaria Executiva, um Comitê de Financiamento e Garantia das Exporta- 


\section{Contenciosos Brasileiros na Organização \\ Mundial do Comércio (OMC)...}

ções, um Conselho Consultivo do Setor Privado (Conex) e um Comitê Executivo de Gestão.

Contudo, o órgão padece da "falta de coordenação e superposição de atribuições e funções" que imperam na institucionalidade da política brasileira de comércio exterior (VEIGA; IGLESIAS, 2002, p. 53-54). Não sobejam, nos últimos anos, resultados afinados em termos de coordenação de políticas pela Camex. Sua fragilidade institucional é constatada como barreira para uma condução eficiente, legítima e transparente da política de comércio exterior brasileira. ${ }^{19}$ Propostas de transformação institucional sugerem "a concentração de poderes em um novo órgão a ser criado ou o deslocamento da Camex de volta à Presidência" (VEIGA, 2007, p. 155), assim como reforço substancial "de capacitação técnica e humana" (VEIGA; IGLESIAS, 2002, p. 92).

Além do arranjo institucional, fatores internacionais parecem explicar o descompasso entre as discussões e deliberações da Camex e as demandas e iniciativas nacionais em matéria de comércio exterior. É, contudo, extremamente difícil qualificar a importância do contexto internacional para o respeito e a conservação das decisões da Camex, uma vez que não há clareza quanto a (i) como os problemas externos são reconhecidos pelo órgão; (ii) como situações colocadas em pauta pelo órgão ou submetidas à sua análise são compreendidas e trabalhadas; ou (iii) como evoluem as interpretações e respostas institucionais, e que papel assume a "memória" do órgão em sua dinâmica decisória (HUDSON; VORE, 1995, p. 224-225).

Ademais, atualmente nenhum dos componentes da Camex, ou mesmo do Executivo, detém oficialmente poder de veto sobre as decisões comerciais de impacto, como o início de litígios internacionais. ${ }^{20}$ Como órgão eminentemente político, desprovido de um corpo burocrático volumoso, a Camex hospeda coalizões e posicionamentos variáveis conforme sua composição e o contexto político. ${ }^{21}$ A necessi- 
dade de consenso, ao contrário de atravancar tais decisões, sinaliza a observadores externos que qualquer deliberação do órgão pode tanto assumir ares definitivos quanto se volatilizar. A alocação da prerrogativa de veto a agente específico, mesmo que interno a um órgão do Executivo, ${ }^{22}$ por outro lado, poderia gerar benefícios institucionais estratégicos, não restritos à negociação internacional (MO, 1995, p. 921).

Daudelin (2005) propõe que os desafios para a formulação da política externa de um país sejam observados a partir de dois eixos estruturais: a vulnerabilidade ao ambiente externo e a complexidade deste ambiente. Vulnerabilidade (importância do cenário externo para dado tema) e complexidade são fatores percebidos, e não dados. ${ }^{23} \mathrm{~A}$ partir do enquadramento dos tópicos de política externa nesses eixos, serão alocados mais ou menos recursos, variarão a margem de ação política, o grau de transparência e consistência das opções tomadas.

É perceptível, no que diz respeito ao segundo eixo de análise, que a formulação da política externa, nos últimos anos, tornou-se mais complexa, com interação entre temas domésticos e internacionais, novos atores e interesses, instituições em fase de consolidação. ${ }^{24}$ Nesse sentido, a Camex seria suficientemente especializada para lidar com a complexidade das decisões relativas ao comércio exterior, desde que apoiada por outros órgãos de objetivos mais específicos, como repartições do MRE.

\section{Tabela 1}

Balança Comercial Brasileira (2006-2005) - US\$ milhões

\begin{tabular}{llll}
\hline & $\mathbf{2 0 0 5}$ & $\mathbf{2 0 0 6}$ & $\Delta \%$ \\
\hline Exportação & 137,471 & 118,308 & 17,1 \\
Importação & 91,394 & 73,599 & 25,2 \\
Saldo & 46,077 & 44,709 & 3,9 \\
Corrente de Comércio & 228,865 & 191,907 & 20,2 \\
\hline
\end{tabular}




\section{Contenciosos Brasileiros na Organização \\ Mundial do Comércio (OMC)...}

\section{Gráfico 1}

Participação das Exportações no PIB do Brasil (1997-2006)

Previsão (\%)

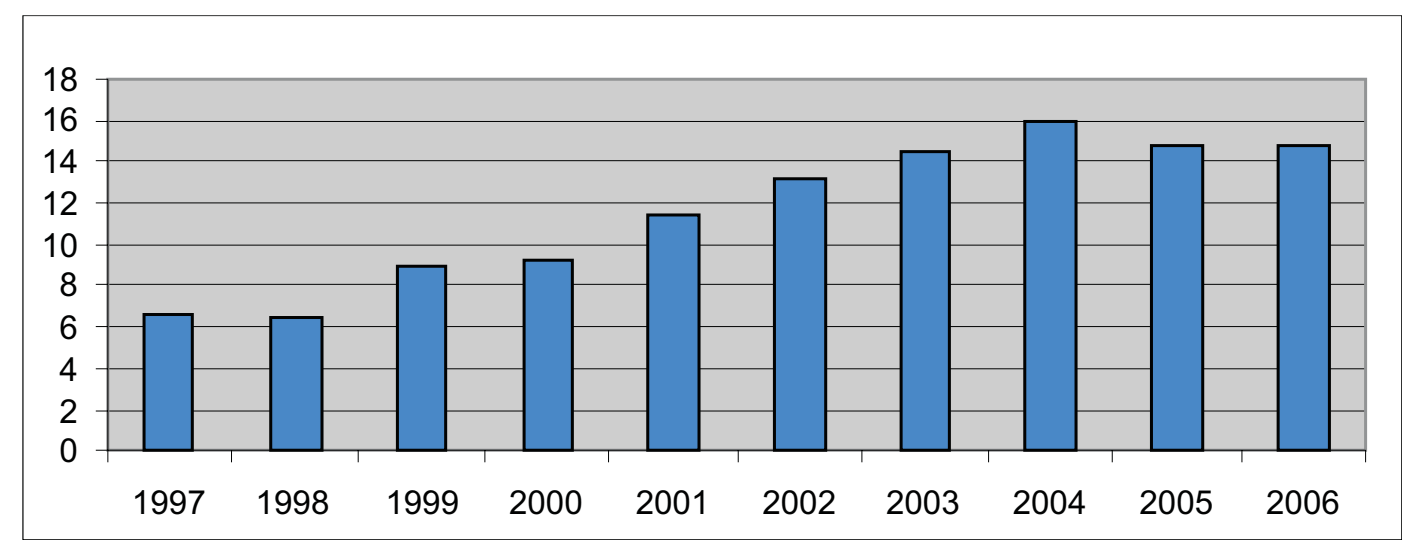

Fonte: Secex/MDIC (DEPLA, 2006, p. 14).

Entretanto, o primeiro eixo de análise, grau de dependência brasileiro das trocas internacionais, afetaria a livre atuação da Camex como órgão de coordenação, bem como seus graus de transparência e, em casos extremos, sua relevância para a definição das políticas decisivas para o país. A corrente de comércio brasileira corresponde hoje a aproximadamente $24 \%$ do produto interno bruto (PIB). ${ }^{25}$ Embora não seja tão representativo quanto o das economias mexicana, chilena ou canadense, por exemplo, o índice da internacionalização da economia brasileira demonstra uma importância inédita do comércio exterior para o Brasil (VEIGA, 2007, p. 79). ${ }^{26}$ Destaca-se o sucesso das exportações, fonte de um saldo comercial relevante.

É facilmente explicável, nesse contexto, que a vulnerabilidade percebida invoque não apenas atenção popular e da mídia sobre o tema, mas também intervenção dos agentes públicos encarregados de sua supervisão, diretamente interessados na condução e no sucesso das políticas relacionadas ao comércio exterior. A suposta constituição de um "núcleo duro" para a política externa, envolvendo a cúpula da Presidência da República, da Casa Civil e do Ministério das Relações Exteriores (VEIGA, 2007, p. 129-130), ${ }^{27}$ representaria assim uma 
resposta à percepção de que a corrente de comércio ganha importância ímpar para a economia brasileira.

Da mesma forma, as decisões estratégicas seriam menos expostas ao escrutínio público, reforçando a concentração de poder no Executivo, que já contava com domínio irrestrito (i) dos instrumentos da política fiscal (incluindo subsídios) e tarifária, no Ministério da Fazenda, ii) da atividade aduaneira a cargo da Secretaria da Receita Federal e (iii) da política comercial, incluindo defesa comercial e barreiras não tarifárias, na Secretaria de Comércio Exterior, subordinada ao MDIC. ${ }^{28}$

Nesse sentido, muito embora tenha a Camex atribuição legal para definir as estratégias comerciais do país, seu mandato político parece limitar-se às decisões de menor alcance (VEIGA, 2007, p. 157). A vocalização de setores ofensivos e defensivos em comércio não teria no órgão seu locus principal. No que diz respeito à seleção de demandas que o Brasil apresenta à $\mathrm{OMC}$, não seria, pois, a Camex a única instância deliberativa, nem mesmo a primordial, considerando que os ministérios não necessariamente submetem determinadas escolhas ao órgão.

Dessa maneira, mesmo que as deliberações sobre contenciosos comerciais não sejam, como enxergam alguns analistas, marcadas por "pulverização de poder e conflitos de competência" (VEIGA; IGLESIAS, 2002, p. 81), estariam sujeitas a incertezas institucionais. A tomada de decisões da Camex, por consenso, indica também que a agenda do órgão pode estacar e que parte de suas resoluções seja constituída antecipadamente, para mera ratificação "coletiva".

Adentrar o plano estatal e dissecar seus processos de decisão implica reconhecer que a Camex, relegada a segundo plano, submete-se a decisões de foros não previstos institucionalmente e não abertos à participação da sociedade civil (VEIGA, 2007). Seu acompanhamento das negociações internacionais, por exemplo, não alcança os contenciosos comerciais. ${ }^{29}$ Parece desempenhar papel mais destacado a 


\section{Contenciosos Brasileiros na Organização Mundial do Comércio (OMC)...}

Coordenação-Geral de Contenciosos (CGC) do MRE, ${ }^{30}$ ainda que institucionalmente tal órgão se ocupe somente da condução das demandas, e não de sua seleção estratégica.

Modelos espaciais explicariam bem a dinâmica decisória da Camex nos litígios internacionais iniciados pelo Brasil? Considera-se que não, justamente por conta da dificuldade de identificar os agentes com poder decisório sobre contenciosos comerciais, da nebulosidade de suas competências, de coalizações extremamente dinâmicas entre os agentes interessados em tais deliberações e de constrições políticas e econômicas desvinculadas do contexto institucional. ${ }^{31}$

\subsection{Moldura(s) para as demandas ao OSC}

De acordo com o avanço da estabilidade econômica e da desvalorização cambial, acompanhado pela redução das barreiras comerciais e por uma forte expansão da economia global, não surpreendem a ampliação do grau de abertura econômica e o aumento do comércio internacional brasileiros. As decisões sobre demandas aos mecanismos de solução de controvérsias comerciais passam, nesse contexto, a interessar mais aos agentes privados.

Tendo o comércio exterior conquistado espaço na pauta de muitos setores econômicos, ${ }^{32}$ assistiu-se no setor público a uma efervescência de mecanismos de participação do setor privado (diálogo e consulta), nem sempre institucionalizados e, portanto, politicamente instáveis (VEIGA, 2007, p. 147-150). Na Camex, essa participação ocorre por meio de vinte representantes no Conex, "aí incluídos representantes da produção, da importação, da exportação, do trabalho e de outros setores profissionais relevantes", ${ }^{33}$ que discutem a coordenação da política externa brasileira, expressando opiniões consultivas.

A despeito dessa previsão, ganha terreno o diagnóstico de que não há mecanismo formal de participação da sociedade civil nas decisões 
sobre política externa (JALES, 2007, p. 58). No campo da política de comércio exterior, reivindicam-se novos instrumentos de consulta, ao mesmo tempo que foros antigos assimilam "associações empresariais e sindicais, com preferência para entidades multissetoriais ou horizontais de representação de interesses" (VEIGA; IGLESIAS, 2002, p. 72). ${ }^{34}$

Porém, "Constrições estruturais não podem ser desfeitas pelo simples desejo" (WALTZ, 1986, p. 106). O debate público sobre políticas de maior alcance esbarra, necessariamente, em constrangimentos macroeconômicos fortes, relacionados tanto a políticas domésticas tributária e cambial, com acentuada influência sobre as exportações, quanto a fatores externos, em especial preços internacionais de commodities e oscilações na demanda internacional por produtos mais sofisticados (VEIGA, 2007, p. 73-79).

Os espaços de deliberação do setor privado, portanto, não dão margem à efetiva análise e à tomada de medidas relativas ao comércio exterior, sem que o Estado assuma o comando e a execução de tais medidas. E, se nas negociações internacionais estas limitações são evidentes, na proposição de demandas ao OSC elas são fulminantes. Nesse esteio, arenas políticas não institucionais recebem as reivindicações empresariais mais amplas, direcionadas principalmente a acesso a mercados, tarifas, instrumentos de defesa comercial, regras de origem e compras governamentais. E indagações sobre possíveis litígios comerciais internacionais são dirigidas a órgãos e interlocutores variáveis, principalmente à Camex, à CGC e às cúpulas do MRE e da Presidência. ${ }^{35}$

Um dos grandes méritos da CGC é a compassada interação com o setor privado. Mesmo sem locus standi no OSC, os grupos de interesse exercem influência marcada sobre os contenciosos. Ainda que os membros da OMC iniciem e conduzam os litígios, muitas de suas empresas se envolvem em tais processos de forma plena, neles inves- 


\section{Contenciosos Brasileiros na Organização Mundial do Comércio (OMC)...}

tindo vastos recursos (KEOHANE; MORAVCSIK; SLAUGHTER, 2000, p. 463). No caso brasileiro, são vistosas as presenças, nos contenciosos comerciais, de acadêmicos, associações de classe, think tanks, consultorias e escritórios de advocacia. ${ }^{36}$

O desenho institucional da Camex, em contrapartida, não parece capaz de combater o "insulamento burocrático e porosidade do Estado a interesses exclusivamente empresariais" (LIMA; SANTOS, 2001, p. 138), potencial resultado do primado da política externa pelo Executivo. ${ }^{37}$ Em termos de recursos, de importância como foro deliberativo e de capacidade de construção de consensos, nota-se a insuficiência do órgão para coordenar a política externa brasileira. À margem da Camex, aprofunda-se uma fragmentação dos loci e dos agentes institucionais incumbidos dos temas comerciais e da atuação brasileira diante de organismos internacionais. ${ }^{38}$

No que diz respeito às disputas comerciais na $\mathrm{OMC}$, porém, é preciso distinguir, de um lado, a seleção de demandas, esfumaçada e desnorteada da perspectiva institucional, e, de outro, a coordenação entre CGC, diplomatas lotados em Genebra, empresas e associações empresariais e escritórios de advocacia. ${ }^{39}$ A condução dos contenciosos, espelhada nesse trabalho conjunto, é elogiada nacional e internacionalmente em larga medida por causa da forte interação entre agentes públicos e privados. 40

\subsection{O Brasil e a escolha de contenciosos na OMC}

O fortalecimento do sistema multilateral do comércio, após a Rodada Uruguai do GATT, impôs ao Brasil que imprimisse traços mais fortes à sua política externa. ${ }^{41}$ Desde 1995 , além de se adequar às novas regras multilaterais, o país precisa lidar com um mecanismo de resolução de disputas reformulado, estruturado, juridicizado e respeitado pelos membros da OMC (LAFER, 1998). ${ }^{42}$ 
É evidente a importância do OSC para a "luta por melhores práticas" no comércio internacional (JACKSON, 2004). A passagem do GATT para a OMC trouxe intensificação de raciocínios técnico-jurídicos na análise dos conflitos levados aos painéis e ao Órgão de Apelação. Ademais, a mudança estrutural na forma de adoção das decisões fortaleceu o OSC, ${ }^{43}$ que tem sido paulatinamente mais acionado. Em paralelo à alteração substancial na fundamentação das decisões, com maior utilização de precedentes, ${ }^{44}$ houve também uma ascensão do grau de respeito às decisões do OSC.

Para o uso efetivo do OSC, um membro da OMC precisa desenvolver meios de identificar as demandas potenciais e organizar sua apresentação de forma precisa, contundente e bem amparada por fatos e argumentos. No caso brasileiro, a criação da CGC, em 2001, representou um passo importante para a qualidade das intervenções no OSC, com trabalhos conjuntos com o setor privado e estratégias não restritas ao curto prazo. ${ }^{45}$ Ainda que aparente caber à Camex a decisão oficial sobre determinada demanda, sua gestação e condução são fortemente centralizadas na CGC. ${ }^{46}$

A liberalização comercial, resultante de tratados, medidas estatais unilaterais ou eliminação de mecanismos de proteção, ao forçar as empresas a se ajustarem a mercados internacionais mais competitivos, modifica suas preferências e estratégias e, conseqüentemente, seu nível de atividade política (HATHAWAY, 1998, p. 584). ${ }^{47}$ É natural, portanto, que a CGC, como ponto focal das disputas do Brasil na $\mathrm{OMC}$, receba contribuições pontuais de diversos atores que, no caso dos procedimentos na OMC, são "empresas ou grupos industriais tipicamente ricos o suficiente para custear contenciosos extensos, que no mais das vezes se constituem de elementos politicamente fortes" (KEOHANE; MORAVCSIK; SLAUGHTER, 2000, p. 486).

Contudo, não há nitidez institucional quanto à responsabilidade pela seleção e autorização das demandas. Essa obscuridade é explicada, 


\section{Contenciosos Brasileiros na Organização \\ Mundial do Comércio (OMC)...}

em parte, pelas vantagens estratégicas inerentes ao poder de seleção das demandas e dos argumentos nelas apresentados. Os reflexos de tais decisões nas atividades institucionais da OMC e nas negociações de regras comerciais dificilmente são ponderados pelos agentes privados, que não compartilham as preocupações de longo prazo dos Estados (TRACHTMAN; MOREMEN, 2003, p. 238-239). ${ }^{48}$

Além de considerações estratégicas externas às demandas propriamente ditas, os membros da OMC são bastante seletivos quanto aos contenciosos, iniciando apenas aqueles cujas chances de vitória parecem mais palpáveis - tendência observada desde a época do GATT. $^{49}$ O Executivo brasileiro teria, assim, incentivos para monopolizar as decisões sobre as demandas propostas ao OSC advindos da preocupação com relações bilaterais determinadas, com as atividades da OMC, com setores econômicos domésticos e com o emprego de recursos humanos e materiais limitados.

A esses condicionantes da ação brasileira no OSC, somam-se expectativas políticas pré-ordenadas, estímulos recebidos do plano internacional (não limitados às negociações das rodadas comerciais), assimetrias e deficiências de informação, e dificuldades políticas para a construção de consensos (HERMANN, 1990, p. 14-20). ${ }^{50}$ Estas restrições à litigiosidade indiscriminada do Brasil na OMC permitem antecipar, ainda que se mantenha nublado o quadro decisório interno ao Executivo, ${ }^{51}$ os eixos de análise relevantes para decisões sobre demandas ao OSC.

\section{Demandas Propostas pelo Brasil ao OSC}

Os órgãos influentes sobre os litígios apresentados pelo Brasil à OMC - Camex e CGC, além da cúpula da Presidência e do Ministério das Relações Exteriores - pertencem ao Executivo. Desvinculados de interesses protecionistas, pouco relevantes para a proposição 


\section{Daniel Arbix}

de demandas ao OSC, esses atores tendem a analisar as possíveis disputas cientes dos constrangimentos descritos acima.

A utilização assimétrica do OSC revela, além da deficiência de recursos, que nem todos os Estados têm incentivos para demandar, seja por incapacidade de retaliar, se for necessário, ${ }^{52}$ seja por parco poder de pressão política para a modificação das medidas julgadas inconsistentes com o sistema multilateral do comércio. ${ }^{53}$ Não obstante, os contenciosos da OMC têm, em geral, sido bem-sucedidos para modificar políticas nacionais e para fomentar mudanças de rumo nas negociações. $^{54}$

Espera-se, desse modo, que a escolha das causas brasileiras obedeça a motivos econômicos e políticos. Os primeiros estão relacionados ao perfil das exportações brasileiras, e os segundos são decorrentes, especialmente, do andamento das negociações comerciais. Tanto nos casos de motivação eminentemente econômica quanto política, os alvos das demandas tendem a deter grande poder de mercado, quer porque os benefícios econômicos de uma decisão favorável do OSC seriam majorados (GUZMAN; SIMMONS, 2005, p. 565), quer porque as primazias econômica e política coincidem nos principais players do comércio internacional. ${ }^{55}$

Conforme esse raciocínio, os demandados seriam, em regra, os principais mercados de exportação dos produtos brasileiros. E os objetos das disputas, isto é, as medidas questionadas, guardariam relação próxima com a pauta de exportação nacional. No que diz respeito a temas de negociação, o esperado é que as reivindicações brasileiras na Rodada Doha sejam ecoadas, mesmo que indiretamente, por alguns dos litígios propostos.

Esse prognóstico, que desconsidera as diferenças de vocalização entre os setores econômicos brasileiros e supõe resultados idênticos para quaisquer arranjos institucionais inscritos no Poder Executivo, é 


\section{Contenciosos Brasileiros na Organização \\ Mundial do Comércio (OMC)...}

desenvolvido na seção abaixo a partir dos dados econômicos recentes sobre o comércio exterior brasileiro.

Para esta análise, serão mensurados apenas os pedidos de consultas feitos pelo Brasil a outros membros da OMC, sem que os procedimentos posteriores sejam levados em consideração. O período do GATT não será analisado, visto que as demandas brasileiras, reduzidas e pouco concentradas no tempo, requereriam análise político-econômica por demais complexa, abarcando do pós-guerra ao começo dos anos 1990, o que ultrapassa os limites deste artigo.

Avaliar a participação do Brasil apenas como demandante se justifica porque tais decisões são mais sensíveis, requerem alocação de mais recursos pelo país e exigem informações abundantes e contatos íntimos com o setor privado. A participação em litígios como terceira parte, por outro lado, requer esforços e recursos mínimos, ${ }^{56}$ sendo normalmente decidida pela CGC, sem formalidades e sem consulta à Camex ou a outras instâncias do Executivo.

\subsection{Resultados esperados}

Embora a corrente de comércio seja extremamente relevante para a economia brasileira, a vulnerabilidade do país ao comércio internacional é mitigada por dois fatores. Primeiro, há dispersão de importadores dos produtos brasileiros, isto é, são muitos os mercados de destino das exportações brasileiras. Os países da Associação Latino-americana de Integração (Aladi) recebem 22,8\% do total das exportações (divididas entre exportações para países do Mercosul, que correspondem a $10,1 \%$ do total, e para outros países da Aladi, $12,7 \%$ ), sendo seguidos pela União Européia com 22,1\%, pelos EUA com $18 \%$ e pelos países da Ásia com $15,1 \%$ das exportações brasileiras (DEPLA, 2006, p. 19). 


\section{Daniel Arbix}

\section{Gráfico 2}

Exportação por Valor Agregado (2006)

Participação (\%)

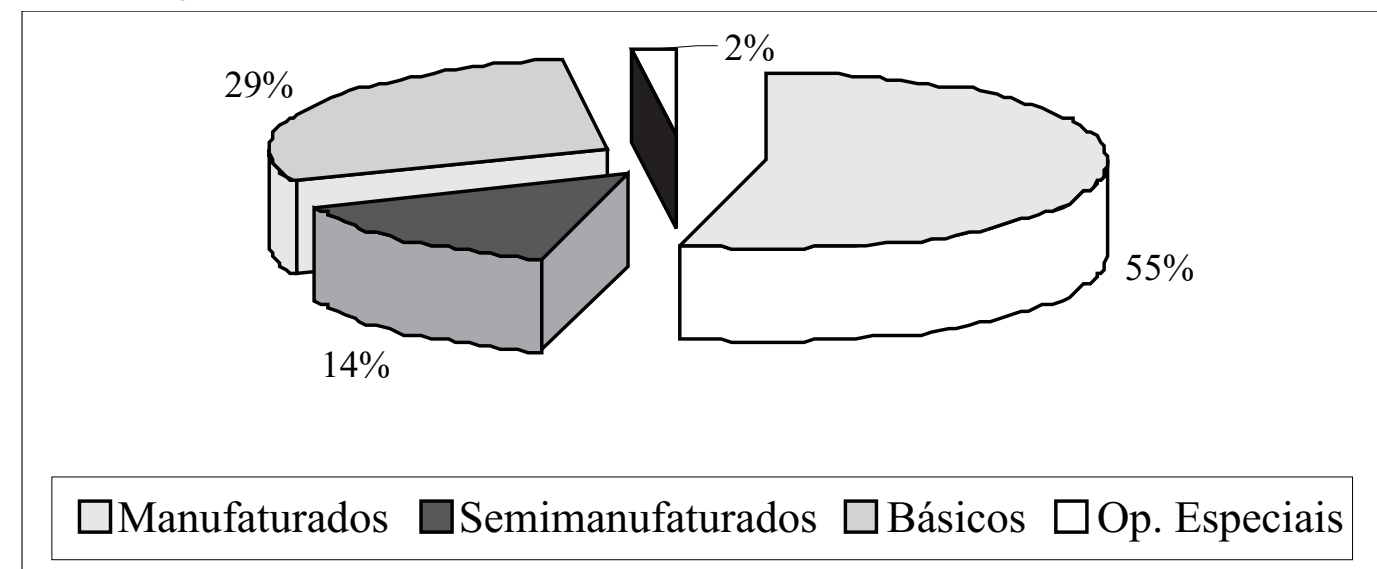

Fonte: Secex/MDIC (DEPLA, 2006, p. 14).

Em segundo lugar, os principais produtos exportados pertencem a variados setores econômicos - os mais relevantes incluem tanto produtos metalúrgicos e químicos quanto produtos como soja, carnes, açúcar e álcool, passando por material de transporte e minérios. As diferenças de participação dos itens da exportação brasileira por valor agregado ratificam essa pulverização da pauta exportadora do país.

Esse quadro tem demonstrado estabilidade nos últimos anos: as exportações em setores distintos têm crescido de forma harmônica, não sendo a evolução de um setor superior à dos demais. ${ }^{57}$ Puga (2007) nota ainda uma escalada das exportações de setores intensivos e naturais, isto é, petróleo e álcool. ${ }^{58}$

É preciso notar que as exportações de bens manufaturados têm valor muito mais relevante do que as demais:

Esse predomínio é globalmente disperso: apenas a União Européia e a Ásia são mercados de destino das exportações brasileiras que recebem mais bens primários do que manufaturados. Juntos, estes mercados representam 37,2\% dos valores de exportação do Brasil; na 


\section{Contenciosos Brasileiros na Organização Mundial do Comércio (OMC)...}

União Européia, entretanto, há equilíbrio de importações entre bens primários e manufaturados. As exportações brasileiras de bens primários, graças à voraz demanda chinesa por insumos, concentram-se na Ásia e correspondem a 60\% do total importado do Brasil, contra $19 \%$ de manufaturados e $21 \%$ de semimanufaturados (DEPLA, 2006, p. 20).

\section{Gráfico 3}

Participação das Classes de Produtos na Pauta de Exportações Brasileira (2006)

Participação (\%)

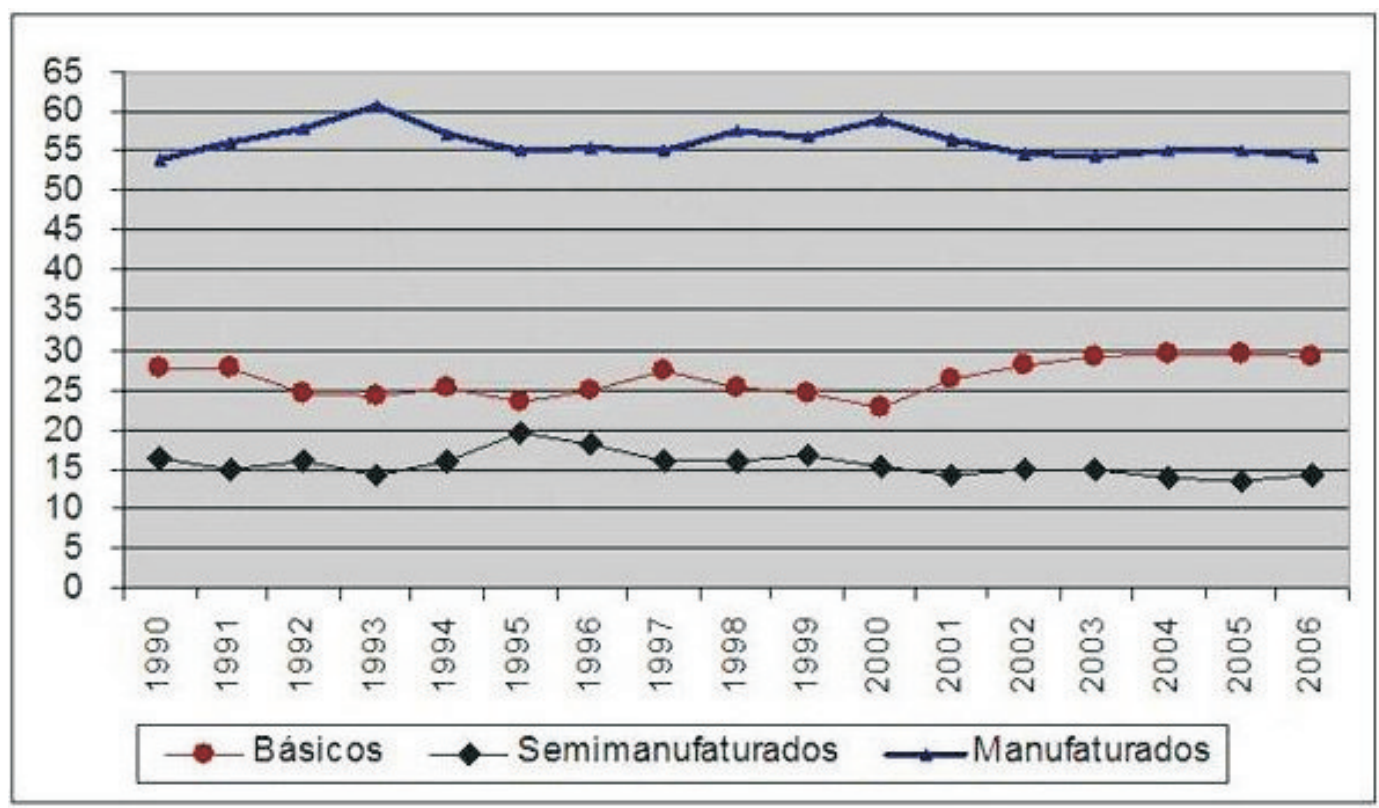

Fonte: Secex/MDIC (DEPLA, 2006).

Diante desse quadro, a expectativa quanto às demandas é que se distribuam entre diversos produtos e países, mas que focalizem bens manufaturados e os principais parceiros comerciais do país, isto é, Estados Unidos, Argentina, os países da União Européia, México, Chile e Japão (DEPLA, 2006, p. 21). ${ }^{59}$ Como principais mercados de exportação dos produtos brasileiros, é esperado que tais países sejam demandados, em especial, com relação a barreiras não tarifárias e medidas de defesa comercial que prejudiquem os produtos mais relevantes na pauta brasileira. 
Supõe-se ainda que as rodadas de negociação da OMC exerçam influência decisiva sobre a postura mais ou menos litigiosa de seus membros, com potenciais picos de demandas apresentadas em determinados períodos críticos de negociação. No que se refere às negociações da Rodada Doha, espera-se nos contenciosos reflexo da contumaz pressão brasileira por acesso a mercados agrícolas e por diminuição de subsídios nos maiores mercados importadores.

Além dos indicadores econômicos e da conjuntura política, para a previsão das demandas brasileiras ao OSC é preciso ter em mente a tendência a "reconvenções", verificada desde o GATT, ${ }^{60}$ ou seja, demandas propostas com finalidade de retaliação. ${ }^{61}$ A seqüência de disputas entre Brasil e Canadá é exemplo claro desta prática, a despeito de normas programáticas da OMC. ${ }^{62}$ Tal fenômeno tende a atenuar o vínculo entre as demandas e os principais setores e parceiros econômicos do país.

Além disso, confrontos comerciais entre Estados com relações bilaterais íntimas, como países fronteiriços ou membros de blocos comerciais comuns, possivelmente são objeto de negociação diplomática intensa, ou são levados a outros mecanismos de solução de controvérsias, antes de desembocarem na OMC. ${ }^{63}$ Por fim, outros casos excepcionais tratados pela literatura também não se enquadram na projeção das demandas ora proposta. ${ }^{64}$

\subsection{Demandas efetivamente submetidas ao OSC $^{65}$}

No que diz respeito à importância dos mercados importadores, as demandas propostas pelo Brasil acompanharam fielmente as previsões relativas à sua pauta de exportações. Nove pedidos de consultas dirigiram-se aos EUA, seis às Comunidades Européias, três ao Canadá, dois à Argentina, um ao México, um à Turquia e um ao Peru. A margem de desvio dos mercados mais relevantes para o Brasil é mínima, 


\section{Contenciosos Brasileiros na Organização \\ Mundial do Comércio (OMC)...}

tendo em vista que o desequilíbrio relativo ao Canadá decorre das contrademandas relativas a subsídios a aeronaves.

\section{Gráfico 4}

Demandados do Brasil ao OSC

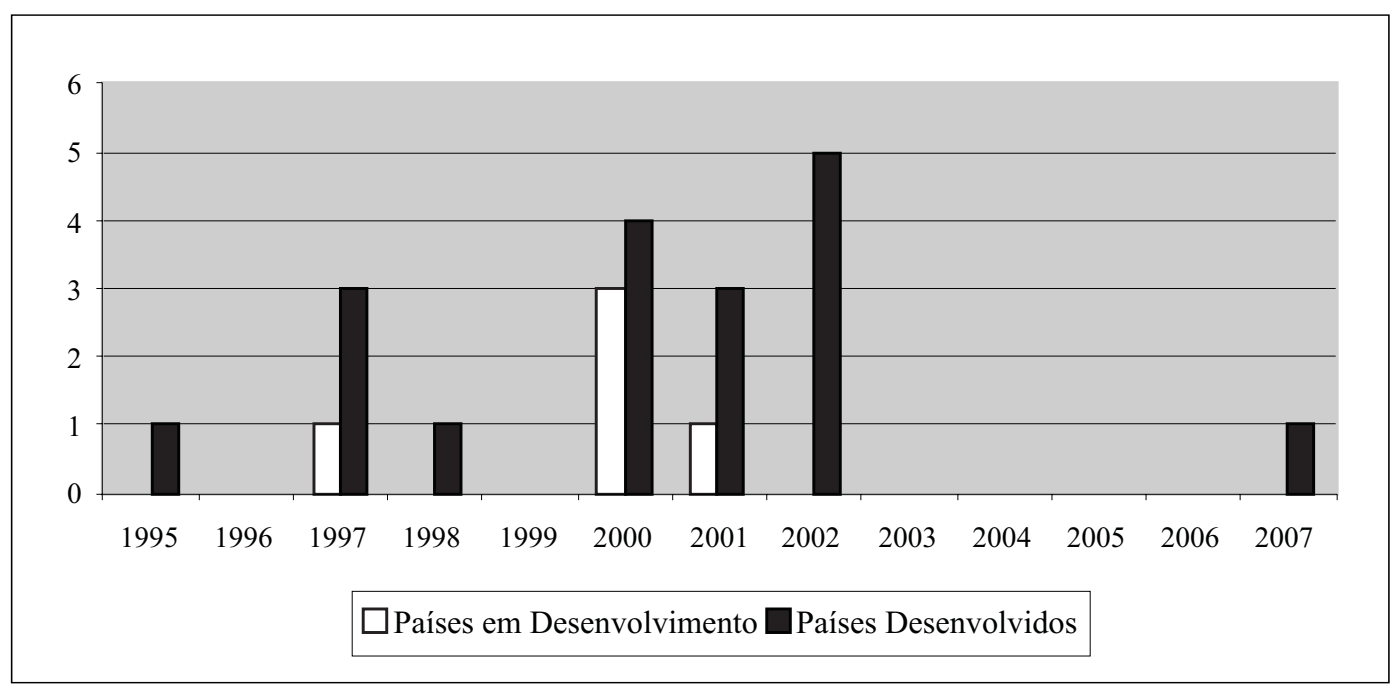

Fonte: Elaboração própria.

Os litígios dirigidos aos países desenvolvidos, dezoito dentre 23, beiram $80 \%$ do total. Este percentual confirma que a escolha estratégica de demandas pelos países pobres privilegia seus mercados principais (GUZMAN; SIMMONS, 2005). Ressalte-se que o fato de Estados Unidos e Europa figurarem como alvos principais está, ainda, em consonância com seu peso político na Rodada Doha.

A análise temática das disputas, por sua vez, é dificultada pela possibilidade de questionamento, no OSC, de regras não diretamente relacionadas a um setor econômico definido. Os benefícios de se questionar normas relativas à propriedade intelectual ou normas de defesa comercial são em princípio sistêmicos, não afetando automaticamente um grupo específico de exportadores. Ademais, as linhas divisórias entre demandas relativas à indústria ou à agricultura não são muito nítidas, assim como as que supostamente apartariam bens manufaturados de semimanufaturados e de primários. 


\section{Daniel Arbix}

\section{Gráfico 5}

Demandas do Brasil ao OSC - Tipo de Demanda

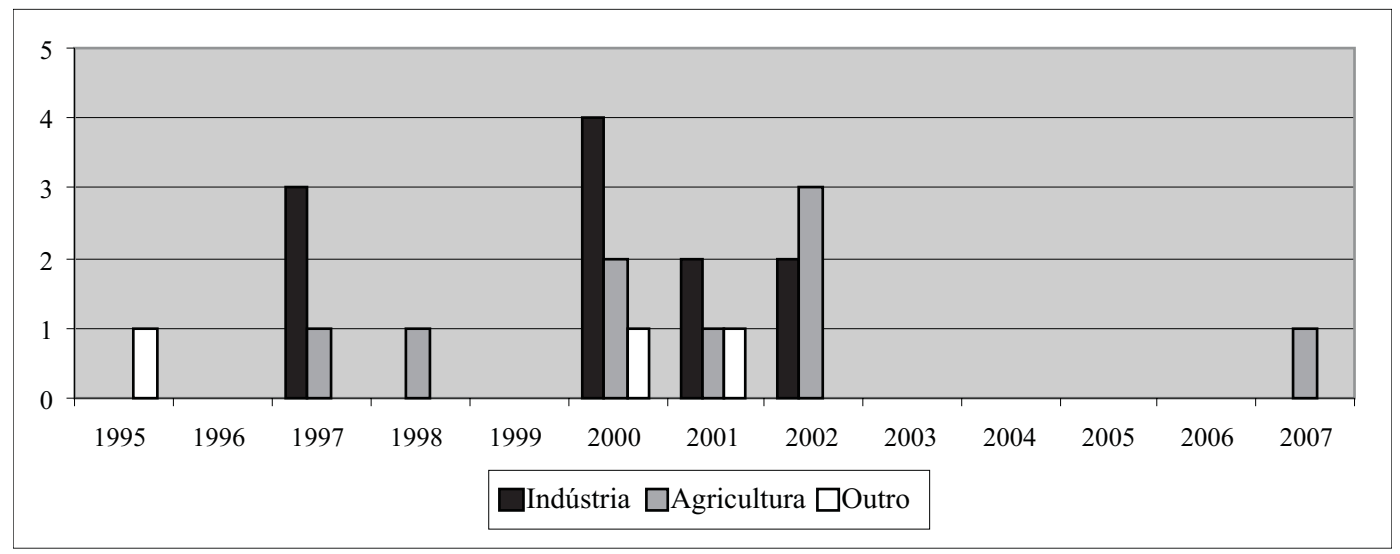

Fonte: Elaboração própria.

Contudo, é possível verificar algumas tendências nas demandas brasileiras. Se forem excluídas dos 23 pedidos de consultas as disputas sobre combustíveis, defesa comercial e propriedade intelectual, ${ }^{66}$ facilita-se uma clivagem das demandas restantes: nove tratam de produtos do agronegócio, ${ }^{67}$ ao passo que as onze restantes dizem respeito a bens industrializados. ${ }^{68}$ Essa proporção visivelmente destoa da pauta exportadora nacional.

A primeira explicação para a quase paridade entre demandas "agrícolas" e "industriais" é normativa. Em substituição às regras vagas e inefetivas do GATT, o Acordo sobre Agricultura da OMC, ainda tímido, colocou ao alcance do OSC problemas relacionados à agricultura, antes resguardados de sua apreciação. ${ }^{69} \mathrm{O}$ aumento das demandas relativas às novas regras agrícolas da OMC corresponde também ao término da Cláusula da Paz, que refreava contenciosos nesse campo.

A segunda explicação é a utilização das demandas como alavanca para as negociações da Rodada Doha. ${ }^{70}$ São reivindicações brasileiras centrais: cortes nas tarifas sobre produtos agrícolas, eliminação dos subsídios à exportação e controles mais impositivos sobre subsí- 


\section{Contenciosos Brasileiros na Organização Mundial do Comércio (OMC)...}

dios domésticos. Os membros da OMC mais resistentes a tais propostas são justamente os Estados Unidos e Comunidades Européias, alvos de oito das nove demandas agrícolas brasileiras. ${ }^{71}$

Auxilia a compreensão de iniciativas agressivas por melhor acesso a esses mercados o fortalecimento do agronegócio competitivo, com setores paulatinamente mais vocais na formulação da política externa brasileira (VEIGA, 2007). A ausência de novas demandas de 2003 a 2006 pode ser explicada, por seu turno, pela continuidade dos múltiplos contenciosos iniciados nos anos anteriores e, também, pela redução significativa de disputas paralelas às negociações mais sensíveis da Rodada Doha (SHAFFER; SANCHEZ; ROSENBERG, 2008, p. 33).

Hathaway (1998) propôs que setores mais expostos à competição internacional tendem a diminuir seu apetite protecionista por conta do ajustamento necessário pelo qual passam, com efeitos sobre a vocalização de suas demandas e sobre a percepção de seus ganhos e necessidades com o protecionismo. Esta assertiva contribui também para explicar a preferência por contenciosos agrícolas, voltados contra subsídios e barreiras não tarifárias menos presentes em mercados liberalizados há mais tempo.

No que diz respeito à importância de produtos individualmente implicados pelos contenciosos, não há divergência relevante entre a pauta exportadora e as demandas apresentadas ao OSC. Dentre os litígios não agrícolas, despontam os relativos à indústria siderúrgica ${ }^{72}$ e à indústria de veículos, ${ }^{73}$ com expressiva participação nas exportações pátrias. Nas disputas agrícolas, as medidas questionadas costumam ter relevância sistêmica mesmo quando relacionadas a produtos pouco influentes isoladamente. ${ }^{74}$ Em vários casos, precedentes da OMC intimidam os legisladores nacionais, que se abstêm de criar novas medidas protecionistas. ${ }^{75}$ 


\subsection{Discussão}

O espectro de demandas submetidas pelo Brasil ao OSC enquadra-se nos resultados projetados a partir de dois componentes essenciais: a pauta exportadora do país e o ambiente negocial da OMC. Previsões futuras, evidentemente, devem incorporar não apenas a evolução da economia doméstica, mas também as pressões e influxos decorrentes da instauração de novas demandas e das disputas em curso. Têm papel incerto o aprendizado institucional na OMC e as reações de seus membros a demandas recorrentes (HERMANN, 1990, p. 10).

Ainda, portanto, que sejam raros os cenários políticos compreensíveis sem explicação institucional (GARRETT; LANGE, 1995, p. 654), no caso da seleção de demandas comerciais internacionais parece haver um considerável descolamento entre as escolhas nacionais e as deliberações dos órgãos de formulação da política brasileira de comércio exterior. E se é certo que "Arranjos institucionais adequados aumentam as probabilidades de sucesso das políticas de comércio exterior" (VEIGA; IGLESIAS, 2002, p. 54), a medida de adequação dos órgãos nacionais é dificultada pela opacidade que circunda as decisões estratégicas sobre o recurso do Brasil ao OSC.

No caso das demandas brasileiras ao sistema multilateral do comércio, as arenas decisórias importam. Mas as previsões institucionais, sejam definidoras do locus decisório na Camex, sejam relativas à participação da sociedade civil, têm influência pouco significativa nessas escolhas, cedendo espaço a fatores econômicos, à atmosfera política da OMC e à vocalização dos setores exportadores. ${ }^{76}$ Embora a interação entre os atores no plano doméstico seja promissora, não é suficiente para indicar tendências ou estratégias de litígio comercial. $^{77}$

A abordagem institucionalista não parece ser suficiente, em síntese, para explicar a seleção brasileira de litígios na $\mathrm{OMC}{ }^{78} \mathrm{~A}$ análise comparada da formulação e da efetividade da política externa sugere 


\section{Contenciosos Brasileiros na Organização Mundial do Comércio (OMC)...}

que as instituições importam, embora possam ficar reféns do jogo político, mas também que exercem papel decisivo as estratégias nacionais, a coordenação institucional, a participação da sociedade civil, os custos de oportunidade e as diferenças culturais (JALES, 2007, p. 67-69). Insinua-se, como agenda de pesquisa futura, a comparação da experiência brasileira com a de países em que as instituições responsáveis pela seleção das demandas ao OSC sejam mais bem definidas. $^{79}$

\section{Conclusões}

Buscou-se com o presente estudo iniciar a abertura da caixa-preta da formulação da política comercial brasileira, ${ }^{80}$ ao menos no singelo caso das demandas brasileiras ao Órgão de Solução de Controvérsias da OMC. À constatação de que esses contenciosos acompanham a pauta de exportação brasileira e são compreendidos no marco das negociações da OMC, soma-se a verificação de que a Camex e a sociedade civil não desempenham funções publicamente reconhecidas para a seleção das disputas. Reforçar a Camex ou reconstruir, por outras vias, a coordenação da política de comércio exterior do Brasil parece imperativo para que, além de bem conduzidos, os contenciosos internacionais sejam escolhidos de maneira mais transparente e atenta aos interesses nacionais.

Os interessados diretos nesta questão específica, sejam agentes públicos, sejam privados, já travam diálogos em inúmeros foros, mediados ou não por órgãos governamentais, em busca das bases para o melhor recurso ao OSC (informações, argumentos e meios de combate).

Para responder a esses novos desafios, o governo e o setor privado deverão atuar em coordenação cada vez mais estreita, visando a melhor identificação dos interesses dos setores exportadores em casos específicos, com otimização 
de esforços, melhor foco e divisão dos trabalhos. (AZEVEDO, 2007, p. 155).

A condução transparente dos debates que antecedem os litígios é crucial para que estratégias bem desenhadas evitem voluntarismo e fragilização de negociações internacionais por conta de demandas escolhidas inadequadamente, seja pelo momento inoportuno do pedido de consultas, seja por fundamentação e preparação impróprias, seja pela opção equivocada quanto aos países envolvidos - quer como demandados, quer como terceiras partes alinhadas ao Brasil. ${ }^{81}$

É evidente, mas necessário reiterar, que as inúmeras constrições sobre as escolhas de demandas no sistema multilateral do comércio são em parte exógenas e impedem que, a partir de estudo nelas focalizado, se deduzam delas opções políticas amplas. ${ }^{82}$ A política externa brasileira deve ser realista quanto aos desafios internacionais e suas margens de manobra, muitas vezes estreitas. Contudo, "Precisamos de uma visão das transformações não como resposta determinista a forças maiores operando no sistema internacional, mas sim como um processo de decisão" (HERMANN, 1990, p. 20).

As decisões sobre contenciosos comerciais, já ousadas por contrariar parceiros econômicos mais fortes, ${ }^{83}$ devem ser também audaciosas pela transparência para que sejam formuladas de modo responsável e bem informado, e também para que os setores exportadores do país emprestem o ímpeto necessário ao processo decisório e às disputas no sistema multilateral do comércio. ${ }^{84}$ 


\section{Contenciosos Brasileiros na Organização Mundial do Comércio (OMC)...}

\section{Notas}

1. Esta e as demais citações de originais em língua estrangeira foram livremente traduzidas para este artigo.

2. O artigo 49 da Constituição da República Federativa do Brasil estabelece como "competência exclusiva do Congresso Nacional [...] resolver definitivamente sobre tratados, acordos ou atos internacionais [...] autorizar o Presidente da República a declarar guerra, a celebrar a paz, a permitir que forças estrangeiras transitem pelo território nacional ou nele permaneçam temporariamente", ao passo que, pelo artigo 22, "Compete privativamente à União legislar sobre: [...] VIII - comércio exterior e interestadual".

3. Lima e Santos (2001, p. 145) ressaltam também o "poder unilateral de definição da agenda externa do país”, desequilíbrio na configuração institucional presidencialista.

4. Conforme o artigo 237 da Constituição Federal de 1988.

5. Diversos autores afirmam ser o Executivo considerado menos propenso a ceder a pressões protecionistas do que o Legislativo. Entre eles, ver Hathaway (1998, p. 609).

6. Mena (2004) descreve processo semelhante no México, onde a liberalização comercial foi liderada pelo Executivo. Contudo, o autor verifica uma recente retomada do Legislativo sobre a política externa, inclusive com autoridade sobre negociações internacionais.

7. Os autores notam que "as posições do presidente, de iniciador da política, e do Congresso, de mero ratificador ex post facto, geram um equilíbrio em que o legislador mediano é obrigado a acatar as políticas negociadas pelo Executivo em fóruns internacionais, a despeito de estarem para além de sua curva de indiferença". Não há, porém, comprovação empírica desta hipótese.

8. Segundo Garrett e Lange (1995, p. 646), competências extensas são delegadas às burocracias, cujas preferências divergem daquelas de representantes eletivos.

9. Artigo 4ำ VII da Constituição Federal de 1988.

10. Mansfield, Milner e Rosendorff (2000, p. 306), em amplo estudo empírico, procuraram demonstrar que regimes democráticos tendem a promover mais liberalização comercial entre si do que ao interagir com regimes autocráticos: "Mantendo constantes vários fatores econômicos e políticos, o comércio entre 


\section{Daniel Arbix}

pares democráticos tende a ser mais livre do que aquele entre pares compostos de uma democracia e uma autocracia".

11. "A escolha do regime de barganhas doméstico afeta o equilíbrio das barganhas internacionais" (MO, 1995, p. 920).

12. Decreto $\mathrm{n}^{\circ} 1.386$, de 6 de fevereiro de 1995 , art. $1^{\circ}$.

13. Decreto $\mathrm{n}^{\circ} 3.756$, de 21 de fevereiro de 2001 .

14. Decreto $n^{\circ} 3.981$, de 24 de outubro de 2001 , art. $1^{\circ}$, $\S 1^{\circ}$.

15. Tais relações, segundo Veiga e Iglesias (2002, p. 63-65), seriam conflituosas na medida em que são delegadas determinadas responsabilidades ao setor privado com transparência reduzida.

16. A criação da Camex parece sintonizada com a assertiva de Daudelin (2005, p. 119) de que os temas internacionais que envolvem alta vulnerabilidade e significante grau de complexidade demandam "um aparato de assuntos externos especializado e forte". A especialização, evidentemente, não é garantia de sucesso.

17. Decreto $n^{\circ} 4.732$, de 10 de junho de 2003, art. $1^{\circ}$. Ao descrever a Camex, Veiga e Iglesias (2002, p. 89) relatam que "Suas funções institucionais principais referem-se à formação do consenso dentro do governo e à eliminação do gap entre a tomada de decisões e sua implementação".

18. O Decreto $\mathrm{n}^{\circ} 5.398$, de 23 de março de 2005 , define os componentes atuais do Conselho de Ministros.

19. Veiga (2007, p. 83, 152), ecoando Veiga e Iglesias (2002, p. 89-90), descreve essa fragilidade: "desde sua criação a CAMEX enfrenta notórias dificuldades para desempenhar sua missão. De um lado, seu status institucional de Câmara da Presidência foi colocado em questão com sua transferência para o MDIC, o que restringiu naturalmente seu poder de coordenação interministerial. De outro, sua capacidade decisória está explicitamente limitada por competências estabelecidas, especialmente na área do Ministério da Fazenda, o que também coloca em xeque sua capacidade de coordenação interministerial. Além disso, dotada de poucos recursos técnicos e humanos, a CAMEX tem dificuldades para acompanhar a implementação de medidas adotadas em seu âmbito e para oferecer ao governo um feedback dos resultados e impactos de suas políticas".

20. No caso brasileiro, não estaria claro o two-level game descrito por Putnam (1988), visto que o modelo de agente principal dificilmente é aplicável ao Congresso, ausente em matéria de política externa. Também não soa factível a 


\section{Contenciosos Brasileiros na Organização Mundial do Comércio (OMC)...}

hipótese de um detentor de veto externo aos Poderes Executivo e Legislativo grupo de interesse, agência governamental ou comitê legislativo - conforme propôs Mo (1995).

21. Embora essa análise indique campo para estudos relacionados aos pontos de veto (TSEBELIS, 1995), não é possível identificar as preferências dos componentes da Camex com clareza ao longo dos anos 1990 e 2000.

22. O poder de veto, compreendido como vantagem estratégica, é mais comumente associado à capacidade do Legislativo de vetar a adoção de tratados internacionais negociados pelo Executivo (MANSFIELD; MILNER; ROSENDORFF, 2000).

23. Daudelin (2005, p. 109) esclarece que "vulnerabilidade e complexidade de qualquer grupo de questões dependem largamente da percepção".

24. A agenda institucional passou a exigir, no âmbito do Executivo, coordenação de diversos ministérios, condição para o sucesso de políticas dependentes de sintonia de recursos escassos e conjuntos de medidas interdependentes (VEIGA, 2007, p. 151).

25. Ver Tabela 1 e Gráfico 1.

26. A essa efusiva constatação, o autor acrescenta que as exportações atualmente têm efeitos expressivos sobre a economia nacional, que adentram decisivamente as estratégias empresariais, e que novos atores e interesses eclodem na arena da política externa (VEIGA, 2007, p. 73-79).

27. Segundo o autor, essa configuração decisória reflete a "visão de que a estratégia de negociação é formulada a partir de uma visão política (por oposição à econômico-pragmática), e de que as discussões dentro do governo se dão apenas dentro dos marcos definidos por aquela visão" (VEIGA, 2007, p. 153). Destaca-se que não há comprovação empírica desta hipótese.

28. Veiga e Iglesias (2002, p. 82-83) ressaltam ainda o papel do Banco Nacional de Desenvolvimento Econômico e Social (BNDES).

29. Listam-se, no setor sobre a OMC na página da Camex na internet, "Histórico, Acordos da OMC, Princípios, Rodadas de Negociação, PaísesMembros, Adesão de novos países, Concessões Tarifárias do Brasil na OMC", mas não os litígios dos quais o Brasil faz parte. Ver elenco disponível em: $<\mathrm{http}$ ///www.desenvolvimento.gov.br/sitio/secex/negInternacionais/acoCome rciais/IndiceOMC.php>. Acesso em: 23 jul. 2007.

30. A CGC, "criada pelo Decreto 3.959 , de 10 de outubro de 2001, é a unidade do Itamaraty que se ocupa da atuação do Brasil no âmbito do mecanismo de 


\section{Daniel Arbix}

solução de controvérsias da Organização Mundial do Comércio (OMC), assim como da participação brasileira em negociações relativas ao Entendimento sobre Solução de Controvérsias da OMC", segundo texto disponível em: <http://www.mre.gov.br/index.php?option=com_content\&task=view\&id= 437\&Itemid=351>. Acesso em: 23 jul. 2007. Não obstante, o Decreto 3.959/01 apenas prevê para a CGC duas funções com gratificação (coordenador geral e assistente), sem especificar as competências do órgão.

31. Não estão presentes, na definição de contenciosos comerciais internacionais, "espaço político bem definido, a informação sobre preferências dos atores definidas dentro desse espaço político e uma agenda especificando as seqüências de políticas a serem votadas" (OLIVEIRA; ONUKI; PEREIRA NETO, 2006, p. 77), premissas para que os modelos espaciais fossem ferramenta analítica adequada.

32. Segundo Veiga (2007, p. 132), as negociações da Área de Livre Comércio das Américas (ALCA) foram o estopim da maior participação do empresariado brasileiro na política nacional de comércio exterior.

33. Artigo 25 do Regimento Interno da Camex, disponível em: $<$ http://www. desenvolvimento.gov.br/arquivo/secex/camex/RegInterno-Resolucaon11-2005.pdf>. Acesso em 22 jul. 2007.

34. Cresce a importância, nesta esfera, da Coalizão Empresarial Brasileira (CEB), capitaneada pela Confederação Nacional da Indústria (CNI) e pela Federação das Indústrias do Estado de São Paulo (FIESP).

35. Veiga e Iglesias (2002, p. 72), contundentes, enxergam a "erosão do monopólio do MRE sobre a política externa" como resultado do crescimento da importância da agenda comercial na política externa brasileira. Não há comprovação empírica desse fenômeno. Souza (2001, p. 94-97) destaca consenso nacional sobre os temas comerciais merecerem atenção singular.

36. Panorama completo e atual desses atores é traçado por Shaffer, Sanchez e Rosenberg (2008). Veiga (2007, p. 135-138) anota como exceção os sindicatos de trabalhadores, que viriam relegando a OMC a plano secundário.

37. $\mathrm{O}$ "acesso privilegiado de atores empresariais às agências decisórias do Executivo", reiterado por Lima e Santos (2001, p. 144), evidentemente se mantém.

38. Conforme Azevedo (2007, p. 150), a CGC "foi criada em 2001 com o objetivo de ser o ponto de convergência das ações do MRE e do governo brasileiro nos assuntos relativos a contenciosos comerciais ao amparo do Mecanismo de Solução de Controvérsias da OMC.". 


\section{Contenciosos Brasileiros na Organização Mundial do Comércio (OMC)...}

39. Embates públicos entre a Advocacia-Geral da União e o MRE anunciam uma provável rediscussão do papel daquele órgão na defesa do Brasil no OSC (o que envolve competências de três ordens: constitucional, técnica e econômica). Ver Oliveira e Delmas (2007), Basile (2007) e Otta e Nogueira (2007).

40. Shaffer, Sanchez e Rosenberg (2008, p. 92-93). Os autores acrescentam que "A mudança em direção a redes público-privadas reflete a mudança na política de desenvolvimento do Brasil, com maior confiança de que os mercados globais e o setor privado exportador aumentem o crescimento econômico".

41. Lima e Santos (2001, p. 139) traçam um panorama das diferentes conduções da política externa brasileira desde o fim da Segunda Guerra Mundial, destacando que "A partir da Rodada Uruguai, ficou claro que o Brasil teria de formular uma agenda positiva de negociações e concessões". Notam também que, desde o governo Collor, a política oficial do Estado brasileiro tem sido a liberalização comercial.

42. Já nos anos 1980, a importância do mecanismo de solução de controvérsias do GATT acentuava-se, com uma mudança nos parâmetros de decisão, tornados mais jurídicos e menos diplomáticos (HUDEC; KENNEDY; SGARBOSSA, 1993, p. 18).

43. "No velho sistema do GATT, as decisões dos painéis precisavam ser afirmadas por consenso, o que dava aos litigantes individuais veto ex post. Sob a menos controladora OMC, em contraste, disputas entre membros são resolvidas por meio de painéis quase-judiciais, cuja decisão prevalece, a menos que revertida pelo voto unânime do Órgão de Solução de Controvérsias, constituído por um representante de cada Estado-membro da OMC" (KEOHANE; MORAVCSIK; SLAUGHTER, 2000, p. 466).

44. Embora não vinculantes, as decisões de painéis e do Órgão de Apelação são comumente utilizadas como fundamento para decisões futuras (LAFER, 1998, p. 125).

45. Para Shaffer, Sanchez e Rosenberg (2008, p. 32-33), “O modelo brasileiro para a resolução de disputas na OMC [...] foi criado em resposta a acontecimentos nos quais, grosso modo, o Brasil estava na defensiva, e não como resultado de uma estratégia proativa, de cúpula". Os autores identificam esses eventos em duas defesas brasileiras (uma contra o Canadá, que questionava incentivos à Empresa Brasileira de Aeronáutica S.A. (Embraer) (DS46), e outra contra os EUA, sobre normas brasileiras prevendo licenciamento compulsório de patentes (DS199)). 


\section{Daniel Arbix}

46. Shaffer, Sanchez e Rosenberg (2008, p. 38) identificam três pilares para a atuação da CGC: sua base em Genebra, seu apoio em Brasília e o contato estreito e perene com o setor privado.

47. Milner e Yoffie (1989) apresentam retrospecto das abordagens teóricas sobre posturas empresariais diante da liberalização comercial, bem como discussões sobre tomada de posição estratégica em oposição a pleitos por protecionismo.

48. Trachtman e Moremen (2003, p. 221) explicitam que "direitos privados de ação no contexto comercial são mais apropriadamente incorporados de forma seletiva, conforme negociações diplomáticas no plano doméstico".

49. Ver estudo empírico amplo de Hudec, Kennedy e Sgarbossa (1993, p. 9-11).

50. "Podemos enquadrar esses desafios como limitações de conhecimento jurídico, dote financeiro e poder político, ou, mais simplesmente, de direito, dinheiro e política" (SHAFFER; SANCHEZ; ROSENBERG, 2008, p. 24). Para Guzman e Simmons (2005, p. 592), "restrições em capacitação [...] relegam os países em desenvolvimento a jogadores táticos, não estratégicos, no regime do comércio internacional".

51. Reinhardt (2001, p. 5-6) recorda que "membros do Executivo são mais bem informados que os legisladores sobre suas chances em litígios no GATT/OMC", porque têm acesso privilegiado aos documentos dos procedimentos perante o OSC e porque têm funcionários mais bem treinados e acostumados a tais contenciosos.

52. Guzman e Simmons (2005), entretanto, demonstram empiricamente que os membros mais pobres da OMC tendem a litigar mais contra os mais fortes (com mercados mais importantes), estratégia mais consistente com sua capacidade reduzida para contenciosos do que com o temor de retaliações.

53. Hudec, Kennedy e Sgarbossa (1993, p. 30-31). Para Keohane, Moravcsik e Slaughter (2000, p. 470), “Declarar um processo ‘juridicizado' não abole a política".

54. Segundo Trachtman e Moremen (2003, p. 233), “especialmente na OMC, a solução de disputas é um aparato subsidiário de governança muito importante. Entre rodadas de negociação, e até em outros momentos, ela é o principal instrumento governamental". Keohane, Moravcsik e Slaughter (2000, p. 472) asseveram que "Quanto mais formalmente independente for um tribunal, mais provável que suas decisões desafiem políticas nacionais". 


\section{Contenciosos Brasileiros na Organização Mundial do Comércio (OMC)...}

55. A resolução de controvérsias, ainda que defectiva, pode abrilhantar a assertiva de que "o direito internacional opera à sombra do poder" (KEOHANE; MORAVCSIK; SLAUGHTER, 2000, p. 458).

56. O Brasil foi terceira parte em 48 disputas, conforme lista disponível em: $<$ http://www.wto.org/english/thewto_e/countries_e/brazil_e.htm >.Acesso em 21 jul. 2007. A CGC, contudo, só traz informações sobre treze desses casos (ver documento "Brasil - Histórico - Casos Encerrados ou Paralisados", disponível em: <http://www2.mre.gov.br/cgc/brasil\%20hist\%C3\%B3rico.doc> e em: $<$ http://www.mre.gov.br/portugues/ministerio/sitios_secretaria/cgc/contenciosos.doc >. Acesso em: 23 jul. 2007.

57. Com a possível exceção do "aumento de participação das exportações de bens de capital e o declínio, bastante acentuado, da participação das exportações das indústrias intensivas em P\&D [Pesquisa e Desenvolvimento]" (MARKWALD; RIBEIRO, 2005, p. 15-16), reduzida, porém, nos últimos anos.

58. O autor sugere que a concentração das pautas de exportação brasileira está relacionada com a China, competidora líder em produtos intensivos em trabalho, e nota "a manutenção da participação de setores mais diretamente associados à geração de desenvolvimento tecnológico e modernização do restante da economia".

59. A adesão muito recente da China à OMC afasta o país do grupo de análise relevante para o presente estudo.

60. "Demandados raramente gostam de ser acionados e muitas vezes retaliarão propondo uma ou mais demandas próprias contra o demandante. Assim, uma aparição como demandante freqüentemente garante pelo menos outra como demandado, e vice-versa" (HUDEC; KENNEDY; SGARBOSSA, 1993, p. 31).

61. "Em jogos de 'tit-for-tat' é útil ter um regimento de demandas bem documentadas "na manga' para conter demandas em represália às primeiras" (KEOHANE; MORAVCSIK; SLAUGHTER, 2000, p. 486).

62. Segundo o artigo 3.10 do Entendimento Relativo a Normas e Procedimentos para Solução de Controvérsias, "Fica ainda entendido que não deverá haver vinculação entre reclamações e contra-reclamações relativas a assuntos diferentes". Tradução brasileira disponível em: http://www.mre.gov.br/portugues/ ministerio/sitios_secretaria/cgc/controversias.doc>. Acesso em: 26 out. 2007. Documento original disponível em: <http://wwww.to.org/english/tratop_e/ dispu_e/dsu_e.htm>. Acesso em: 22 jul. 2007. 


\section{Daniel Arbix}

63. Em conjunto com a carência de recursos, esses seriam os principais motivos para a contenção, certamente existente, da litigiosidade comercial internacional (GUZMAN; SIMMONS, 2005, p. 591).

64. Fogem às previsões contenciosos iniciados por força de "valor de longo prazo como precedente" ou "uma reputação empedernida em conflitos comerciais” (GUZMAN; SIMMONS, 2005, p. 567).

65. O Anexo I lista os 23 pedidos de consultas apresentados pelo Brasil ao OSC desde a criação da OMC em 1994.

66. Respectivamente, DS4, DS217 e DS224 (ver Anexo I).

67. DS69, DS154, DS209, DS241, DS250, DS266, DS267, DS269 e DS365 (ver Anexo I).

68. DS70, DS71, DS112, DS190, DS208, DS216, DS218, DS219, DS222, DS239 e DS259 (ver Anexo I).

69. Hudec, Kennedy e Sgarbossa (1993, p. 72-73). Os autores notam que os casos agrícolas, como porcentagem do total de demandas propostas, aumentaram significativamente desde a criação do GATT (HUDEC; KENNEDY; SGARBOSSA, 1993, p. 66-68); e que, para atingir altos índices de sucesso em suas reclamações, "os demandantes agrícolas obviamente aprenderam a selecionar cuidadosamente os casos, de sorte a evitar os vários 'buracos negros' nas normas sobre agricultura do GATT" (HUDEC; KENNEDY; SGARBOSSA, 1993, p. 73).

70. "É impossível julgar a efetividade do braço judicial da OMC - o sistema de solução de controvérsias da OMC - sem também examinar os impactos sobre o braço legislativo (ou de negociações) da OMC. Não há dúvida que as negociações da corrente Rodada Doha sobre agricultura foram impactadas pelos resultados do caso U.S. - Cotton" (ANDERSEN, 2006).

71. A exceção foi a disputa sobre frangos com a Argentina, DS241 (ver Anexo I).

72. Cinco contenciosos: DS208, DS218, DS219, DS239 e DS259 (ver Anexo I).

73. Quatro contenciosos: DS70, DS71, DS112 e DS222 (ver Anexo I).

74. No contencioso US - Upland Cotton, DS267, por exemplo, a pequena relevância comercial do algodão para o Brasil pesa pouco, na avaliação de sucesso do caso, se comparada à incessante cobertura da imprensa internacional e aos efeitos sobre os membros da OMC no contexto de negociações. 


\section{Contenciosos Brasileiros na Organização Mundial do Comércio (OMC)...}

75. Andersen (2006) enxerga esse "chilling effect" de modo concreto: "Os numerosos questionamentos bem-sucedidos a ações não conformes à OMC nos últimos dez anos levaram funcionários de política comercial e legisladores em muitos países-membros da OMC a tomarem em consideração as implicações na OMC de suas ações, ao elaborarem leis e regras".

76. Não se parece confirmar, no caso das escolhas de demandas propostas ao OSC, o primado dos agentes societais como premissa para teorias liberais das relações internacionais. Ainda assim, a clara representação de interesses domésticos refletida em tais decisões, bem como a interdependência no sistema internacional, sugerem campo de estudos potencialmente fértil para a matriz teórica liberal (MORAVCSIK, 1997).

77. Tais explicações, não desenvolvidas neste artigo, são esperadas do campo da escolha racional ou estratégica, "em que é importante o aspecto interativo entre os atores e não a arena" (OLIVEIRA; ONUKI; PEREIRA NETO, 2006, p. $78)$.

78. Grifamos, portanto, a identificação de tendências pela análise institucionalista: "os efeitos de mediação das instituições políticas formais sobre o relacionamento entre preferências [societais*] e resultados políticos tendem a gerar fortes conseqüências" (GARRETT; LANGE, 1995, p. 648).

* Tradução literal do termo em inglês. [Nota do Editor]

79. Os EUA cumprem esse requisito com o Office of the United States Trade Representative (USTR).

80. Emprestamos a expressão de Hudson e Vore (1995, p. 211), que sublinham "abrir a caixa-preta do processo decisório sobre política externa adiciona muitos detalhes à análise das relações internacionais”.

81. Relembre-se a advertência contumaz de Daudelin (2005, p. 120): "Continuar pensando que boas intenções ou maneiras podem efetivamente dirigir uma política de comércio exterior é um delírio”.

82. "a política externa se torna inteligível somente à medida que suas fontes, conteúdos e consequiências são considerados em conjunto" (ROSENAU, 1968, p. 316).

83. Waltz (1986, p. 105) lembra que "Enquanto a estrutura não for afetada, não é possível que mudanças nas intenções e ações de atores particulares produzam os resultados desejados ou evitem os indesejados".

84. "O potencial benefício de voz e a chance percebida de sucesso são os dois fatores-chave que determinam as estratégias comerciais dos grupos produtores" (HATHAWAY, 1998, p. 579). 


\section{Referências} Bibliográficas

ANDERSEN, Scott D. The US - Upland cotton decision and the effectiveness of the WTO dispute settlement system. 2006. Trabalho apresentado na Conferência Anual do Instituto de Direito do Comércio Internacional e Desenvolvimento - Comércio internacional e desenvolvimento: um passo além da OMC, São Paulo, IDCID.

ARBIX, Daniel do Amaral. Pacificação do comércio internacional? A participação dos países em desenvolvimento nos contenciosos da OMC. Revista Jurídica do Centro de Pesquisa de Estudos da Subchefia para Assuntos Jurídicos da Casa Civil da Presidência da República, Brasília, v. 8, n. 83, 2007. Disponível em: <http://www.planalto.gov.br/ccivil_03/revista/revista juridica/index.htm>. Acesso em: 13 abr. 2007.

AZEVEDO, Roberto. Contenciosos agrícolas na OMC. In: BAPTISTA, L. O.; CELli Jr., U.; YANOVICH, A. (Org.). 10 anos de OMC. São Paulo: Lex, 2007. p. 149-155.

BASILE, Juliano. Nova Procuradoria vai atuar no exterior. Valor Econômico, 3 ago. 2007.

COUTO, Cláudio Gonçalves; ARANTES, Rogério Bastos. Constituição, governo e democracia no Brasil. Revista Brasileira de Ciências Sociais, São Paulo, v. 21, n. 6, p. 41-62, 2006.

DAUDELIN, Jean. Bubbling up, trickling down, seeping out: the transformation of Canadian foreign policy. In: CARMENT, D.; HAMPSON, F. O.; HILLMER, N. (Ed.). Canada among nations 2004 - setting priorities straight. Montreal: McGill-Queen's University Press, 2005. p. 103-122.

DEPLA - Departamento de Planejamento e Desenvolvimento do Comércio Exterior, Secex/MDIC. Balança comercial brasileira - dados consolidados. Brasília: Ministério do Desenvolvimento, Indústria e Comércio Exterior (MDIC), 2006.

GARRETT, Geoffrey; LANGE, Peter. Internationalization, institutions, and political change. International Organization, New York, v. 49, n. 4, p. 627-655, 1995. 


\section{Contenciosos Brasileiros na Organização Mundial do Comércio (OMC)...}

GUZMAN, Andrew T.; SIMMONS, Beth A. Power plays and capacity constraints: the selection of defendants in World Trade Organization disputes. The Journal of Legal Studies, Chicago, v. 34, n. 2, p. 557-598, 2005.

HATHAWAY, Oona A. Positive feedback: the impact of trade liberalization on industry demands for protection. International Organization, New York, v. 52, n. 3, p. 575-612, 1998.

HERMANN, Charles F. Changing course: when governments choose to redirect foreign policy. International Studies Quarterly, Denton, v. 34, n. 1, p. 3-21, 1990.

HUDEC, Robert E.; KENNEDY, Daniel L. M.; SGARBOSSA, Mark. A statistical profile of GATT dispute settlement cases: 1948-1989. Minnesota Journal of Global Trade, Minneapolis, v. 2, n. 1, p. 2-100, 1993.

HUDSON, Valerie M.; VORE, Christopher S. Foreign policy analysis yesterday, today, and tomorrow. Mershon International Studies Review, Syracuse, v. 39, n. 2, p. 209-238, 1995.

JACKSON, John H. International law status of WTO dispute settlement reports: obligation to comply or option to buy out? American Journal of International Law, Washington, DC, v. 98, n. 1, p. 109-125, 2004.

JALES, Mário. Executive summary: trade policy in Latin America, the United States and the European Union. In: JANK, M. S.; SILBER, S. D. (Coord.). Políticas comerciais comparadas: desempenho e modelos organizacionais. São Paulo: Singular, 2007. p. 11-70.

KEOHANE, Robert O.; MORAVCSIK, Andrew; SLAUGHTER, Anne-Marie. Legalized dispute resolution: interstate and transnational. International Organization, New York, v. 54, n. 3, p. 457-488, 2000.

LAFER, Celso. A OMC e a regulamentação do comércio internacional: uma visão brasileira. Porto Alegre: Livraria do Advogado, 1998.

LIMA, Maria Regina Soares de; SANTOS, Fabiano. O Congresso e a política de comércio exterior. Lua Nova - Revista de Cultura e Política, São Paulo, n. 52, p. 121-149, 2001.

MANSFIELD, Edward D.; MILNER, Helen V.; ROSENDORFF, Peter. Free to trade: democracies, autocracies, and international trade. The American Political Science Review, Washington, DC, v. 94, n. 2, p. 305-321, 2000. 


\section{Daniel Arbix}

MARKWALD, Ricardo; RIBEIRO, Fernando. Análise das exportações brasileiras sob a ótica das empresas, dos produtos e dos mercados. Revista Brasileira de Comércio Exterior, Rio de Janeiro, n. 85, p. 3-20, 2005. Disponível em: <http://funcex.com/material/rbce/85-RMFR.pdf>. Acesso em: 21 jul. 2007.

MENA, Antonio Ortiz. O processo de formulação da política de comércio nas Américas: lições da experiência mexicana. Revista Brasileira de Comércio Exterior, Rio de Janeiro, n. 79, p. 65-79, 2004. Disponível em: <http://www. funcex.com.br/material/rbce/79-g20-ANDT.pdf>. Acesso em: 23 jul. 2007.

MILNER, Helen V.; KUBOTA, Keiko. Why the move to free trade? Democracy and trade policy in the developing countries. International Organization, New York, v. 59, n. 1, p. 107-143, 2005. Disponível em: <http://journals.cambridge.org/download.php?file =\%2FINO\%2FINO59_01\%2FS 002081830505006 Xa.pdf $\&$ code $=93 \mathrm{cc} 1463 \mathrm{cf} 54 \mathrm{bb} 160244640216120 \mathrm{c} 97 \mathrm{>}$. Acesso em: 30 jul. 2007.

MILNER, Helen V.; ROSENDORFF, Peter. Democratic politics and international trade negotiations: elections, and divided governments as constraints on trade liberalization. The Journal of Conflict Resolution, New Haven, v. 41, n. 1, p. 117-146, 1997.

MILNER, Helen V.; YOFFIE, David B. Between free trade and protectionism: strategic trade policy and a theory of corporate trade demands. International Organization, New York, v. 43, n. 2, p. 239-272, 1989.

MO, Jongryn. Domestic institutions and international bargaining: the role of agent veto in Two-Level Games. The American Political Science Review, Washington, DC, v. 89, n. 4, p. 914-924, 1995.

MORAVCSIK, Andrew. Taking preferences seriously: a liberal theory of international politics. International Organization, New York, v. 51, n. 4, p. 513-553, 1997.

OLIVEIRA, Eliane; DELMAS, Maria Fernanda. AGU trava disputa com Itamaraty no exterior. O Globo, Rio de Janeiro, 3 ago. 2007. Economia.

OLIVEIRA, Amâncio Jorge; ONUKI, Janina; PEREIRA NETO, Manoel Galdino. Modelos espaciais na teoria de coalizões internacionais: perspectivas e críticas. BIB - Revista brasileira de Informação Bibliográfica em Ciências Sociais, São Paulo, n. 61, p. 71-89, 2006. 


\section{Contenciosos Brasileiros na Organização Mundial do Comércio (OMC)...}

OTTA, Lu Aiko; NOGUEIRA, Rui. Projeto cria atrito entre Itamaraty e AGU, O Estado de S. Paulo. 4 ago. 2007. Economia.

PUGA, Fernando Pimentel. Petróleo e álcool mudam a pauta exportadora brasileira. BNDES - Visão do Desenvolvimento, Rio de Janeiro, n. 33, 2007. Disponível em: <http://www.bndes.gov.br/conhecimento/visao/visao_ 33.pdf>. Acesso em: 24 jul.2007.

PUTNAM, Robert D. Diplomacy and domestic politics: the logic of Two-Level Games. International Organization, New York, v. 42, n. 3, p. 427-460, 1988.

REINHARDT, Eric. Tying hands without a rope: rational domestic response to international institutional constraints. Trabalho apresentado, Emory University, Department of Political Science, Atlanta, GA. 2001.

ROSENAU, James N. Comparative foreign policy: fad, fantasy, or field? International Studies Quarterly, Denton, v. 12, n. 3, p. 296-329, 1968.

SHAFFER, Gregory; SANCHEZ, Michelle Ratton; ROSENBERG, Barbara. The trials of winning at the WTO: what lies behind Brazil's success. Cornell International Law Journal, v. 41, n. 2, 2008. Disponível em: <http://ssrn.com/ abstract=1137905>. Acesso em: 26 jun. 2008.

SOUZA, Amaury de. A agenda internacional do Brasil: um estudo sobre a comunidade brasileira da política externa. Rio de Janeiro: CEBRI, 2001. Disponível em: <http://www.cebri.org.br/pdf/101_PDF.pdf>. Acesso em: 30 jun. 2007.

TRACHTMAN, Joel P.; MOREMEN, Philip M. Costs and benefits of private participation in WTO dispute settlement: whose right is it anyway? Harvard International Law Journal, Cambridge, v. 44, n. 1, p. 221-250, 2003.

TSEBELIS, George. Decision making in political systems: veto players in presidentialism, parliamentarism, multicameralism, and multipartyism. British Journal of Political Science, Essex, v. 25, n. 3, p. 289-326, 1995.

VEIGA, Pedro da Motta. Política comercial no Brasil: características, condicionantes domésticos e policy-making. In: JANK, M. S.; SILBER, S. D. (Coord.). Políticas comerciais comparadas: desempenho e modelos organizacionais. São Paulo: Singular, 2007. p. 71-162.

; IGLESIAS, Roberto Magno. A institucionalidade da política brasileira de comércio exterior. In: CASTELAR, A.; MARKWALD, R. PEREIRA, L. V. (Org.). O desafio das exportações. Rio de Janeiro: BNDES, 2002. p. 51-96. 
Disponível em: <http://www.bndes.gov.br/conhecimento/ livro_desafio/Relatorio-03.pdf>. Acesso em: 2 jul. 2007.

WALTZ, Kenneth N. Anarchic orders and balances of power. In: KEOHANE, R. O. (Org). Neorealism and its critics. New York: Columbia University Press, 1986. p. 98-130. 


\section{Contenciosos Brasileiros na Organização \\ Mundial do Comércio (OMC)...}

\section{Anexo I \\ Demandas Propostas pelo Brasil ao OSC}

\begin{tabular}{|c|c|c|}
\hline Demanda & Pedido de Consultas & Código \\
\hline $\begin{array}{l}\text { United States - Domestic Support and } \\
\text { Export Credit Guarantees for } \\
\text { Agricultural Products }\end{array}$ & 11 de julho de 2007 & DS365 \\
\hline $\begin{array}{l}\text { European Communities - Customs } \\
\text { Classification of Frozen Boneless } \\
\text { Chicken Cuts }\end{array}$ & 11 de outubro de 2002 & DS269 \\
\hline $\begin{array}{l}\text { United States - Subsidies on Upland } \\
\text { Cotton }\end{array}$ & 27 de setembro de 2002 & DS267 \\
\hline $\begin{array}{l}\text { European Communities - Export } \\
\text { Subsidies on Sugar }\end{array}$ & 27 de setembro de 2002 & DS266 \\
\hline $\begin{array}{l}\text { United States - Definitive Safeguard } \\
\text { Measures on Imports of Certain Steel } \\
\text { Products }\end{array}$ & 21 de maio de 2002 & DS259 \\
\hline $\begin{array}{l}\text { United States - Equalizing Excise Tax } \\
\text { Imposed by Florida on Processed } \\
\text { Orange and Grapefruit Products }\end{array}$ & 20 de março de 2002 & DS250 \\
\hline $\begin{array}{l}\text { Argentina - Definitive Anti-Dumping } \\
\text { Duties on Poultry from Brazil }\end{array}$ & 7 de novembro de 2001 & DS241 \\
\hline $\begin{array}{l}\text { United States - Anti-Dumping Duties on } \\
\text { Silicon Metal from Brazil }\end{array}$ & 18 de setembro de 2001 & DS239 \\
\hline United States - US Patents Code & 31 de janeiro de 2001 & DS224 \\
\hline $\begin{array}{l}\text { Canada - Export Credits and Loan } \\
\text { Guarantees for Regional Aircraft }\end{array}$ & 22 de janeiro de 2001 & DS222 \\
\hline $\begin{array}{l}\text { European Communities - Anti-Dumping } \\
\text { Duties on Malleable Cast Iron Tube or } \\
\text { Pipe Fittings from Brazil }\end{array}$ & 21 de dezembro de 2000 & DS219 \\
\hline $\begin{array}{l}\text { United States - Countervailing Duties } \\
\text { on Certain Carbon Steel Products from } \\
\text { Brazil }\end{array}$ & 21 de dezembro de 2000 & DS218 \\
\hline $\begin{array}{l}\text { United States - Continued Dumping } \\
\text { and Subsidy Offset Act of } 2000 \text { (Outros } \\
\text { reclamantes: Austrália, Chile, } \\
\text { Comunidades Européias, Coréia, Índia, } \\
\text { Indonésia, Japão, Tailândia) }\end{array}$ & 21 de dezembro de 2000 & DS217 \\
\hline $\begin{array}{l}\text { Mexico - Provisional Anti-Dumping } \\
\text { Measure on Electric Transformers }\end{array}$ & 20 de dezembro de 2000 & DS216 \\
\hline
\end{tabular}


Daniel Arbix

\begin{tabular}{|l|l|l|}
\hline $\begin{array}{l}\text { European Communities - Measures } \\
\text { Affecting Soluble Coffee }\end{array}$ & 12 de outubro de 2000 & DS209 \\
\hline $\begin{array}{l}\text { Turkey - Anti-Dumping Duty on Steel } \\
\text { and Iron Pipe Fittings }\end{array}$ & 9 de outubro de 2000 & DS208 \\
\hline $\begin{array}{l}\text { Argentina - Transitional Safeguard } \\
\text { Measures on Certain Imports of Woven } \\
\text { Fabric Products of Cotton and Cotton } \\
\text { Mixtures Originating in Brazil }\end{array}$ & 11 de fevereiro de 2000 & DS190 \\
\hline $\begin{array}{l}\text { European Communities - Measures } \\
\text { Affecting Differential and Favourable } \\
\text { Treatment of Coffee }\end{array}$ & 7 de dezembro de 1998 & DS154 \\
\hline $\begin{array}{l}\text { Peru - Countervailing Duty } \\
\text { Investigation against Imports of Buses } \\
\text { from Brazil }\end{array}$ & 23 de dezembro de 1997 & DS112 \\
\hline $\begin{array}{l}\text { Canada - Measures Affecting the } \\
\text { Export of Civilian Aircraft }\end{array}$ & 10 de março de 1997 & DS71 \\
\hline $\begin{array}{l}\text { Canada - Measures Affecting the } \\
\text { Export of Civilian Aircraft }\end{array}$ & 10 de março de 1997 & DS70 \\
\hline $\begin{array}{l}\text { European Communities - Measures } \\
\text { Affecting Importation of Certain Poultry } \\
\text { Products }\end{array}$ & 24 de fevereiro de 1997 & DS69 \\
\hline $\begin{array}{l}\text { United States - Standards for } \\
\text { Reformulated and Conventional } \\
\text { Gasoline }\end{array}$ & 10 de abril de 1995 \\
\hline
\end{tabular}

Resumo

\section{Contenciosos Brasileiros na Organização Mundial do Comércio (OMC): Pauta Comercial, Política e Instituições}

O presente estudo busca analisar a formulação da política comercial brasileira, de relevância e complexidade crescentes, no caso das demandas brasileiras ao Órgão de Solução de Controvérsias (OSC) da Organização Mundial do Comércio (OMC). Examina-se a centralização de tal política no Poder Executivo com foco em seus processos decisórios, a partir do contexto econômico e político pertinente para a seleção das demandas apresentadas a tal mecanismo de solução de controvérsias. Além de se perscrutar o funciona- 


\section{Contenciosos Brasileiros na Organização Mundial do Comércio (OMC)...}

mento da Câmara de Comércio Exterior (Camex) e sua interação com outros órgãos estatais, investiga-se a dinâmica da condução dos contenciosos e de suas repercussões na agenda comercial da OMC. Constata-se que, à margem do desenho institucional focalizado na Camex, a escolha das demandas responde à pauta comercial e ao impacto nas negociações internacionais do país, acompanhando a pauta de exportação e os principais parceiros comerciais do Brasil, no marco da Rodada Doha da OMC. Marcadas por constrangimentos internos e externos, portanto, as estratégias sobre litígios comerciais internacionais demandam transparência e cooperação aperfeiçoadas com o setor privado.

Palavras-chave: Política de Comércio Exterior - Organização Mundial do Comércio (OMC) - Solução de Controvérsias - Processo Governamental - Instituições - Câmara de Comércio Exterior (Camex)

\section{Abstract}

\section{Brazil Litigation in the WTO: Trade Mix, Politics and Institutions}

This study seeks to analyze Brazil's foreign trade policy, which is of growing importance and complexity, in the particular case of litigation with the WTO's Dispute Settlement Body. Such policy centralization with the Executive Branch is examined with focus on the decision making processes, with grounds on the political and economical context relevant to the selection of disputes to be initiated with the mentioned dispute settlement mechanism. Brazilian Chamber of Foreign Commerce (Camex)'s operations are scrutinized, as well as its interactions with other state bodies, which is followed by an investigation of the dynamics of the disputes' conduction and their repercussion on the WTO's trade agenda. Perceived results are that, despite decisions in respect to the litigation with the WTO's Dispute Settlement Body being centralized with Camex, dispute settlement decisions correspond to the country's trade mix and strategic international negotiation positions, and are closely connected to the Brazilian exports and major trade partners. Shaped by internal and external constraints, therefore, the strategies related to international trade disputes require enhanced transparency and cooperation with the private sector.

Keywords: Foreign Trade Policy - World Trade Organization (WTO) Dispute Settlement - Governmental Process - Institutions - Camex 